\title{
Species-specific patterns in the vulnerability of carbon-starved bacteria to protist grazing
}

\author{
Ruth Anderson ${ }^{1}$, Staffan Kjelleberg ${ }^{2,3}$, Diane McDougald ${ }^{2,3}$, Klaus Jürgens ${ }^{1, *}$ \\ ${ }^{1}$ Leibniz Institute for Baltic Sea Research, Department of Biological Oceanography, Seestrasse 15, \\ 18119 Rostock-Warnemünde, Germany \\ ${ }^{2}$ The School of Biotechnology and Biomolecular Sciences, University of New South Wales, \\ 2052 Sydney, Australia \\ ${ }^{3}$ The Centre for Marine Bio-Innovation, University of New South Wales, 2052 Sydney, Australia
}

\begin{abstract}
Many heterotrophic bacteria possess adaptations for prolonged survival under carbon and energy limitation, generally involving a reduction in cell size and an increased resistance to environmental stress factors. In order to reveal whether carbonstarved bacteria also become less vulnerable to protist grazing, we compared the growth of a bacterivorous nanoflagellate, Cafeteria roenbergensis, on different physiological states of 3 bacterial strains with well-studied starvation responses (Vibrio vulnificus, Photobacterium angustum and Sphingopyxis alaskensis). Protists achieved high growth rates on all 3 bacterial strains when they were provided in a non-starved state. However, for carbon-starved bacteria, pronounced differences in the response of the flagellates were observed. $P$. angustum provided similar protist growth for an equal biomass of nonstarved and starved cultures, indicating no change in food quality or grazing resistance for carbon-starved cells, despite smaller cell size. In contrast, starved $V$. vulnificus did not support protist growth, even resulting in a strong decrease in flagellate numbers at most concentrations tested; and starved $S$. alaskensis provided only reduced growth rates. Our results demonstrate that (1) feeding on bacteria of smaller cell size does not necessarily impose energy constraints on a flagellate grazer, and (2) a pronounced species-specific variability exists in the susceptibility of carbon-starved bacteria to protist grazing.
\end{abstract}

KEY WORDS: Grazing vulnerability - Carbon starvation $\cdot$ Growth rate $\cdot$ Protist $\cdot$ Bacteria

Resale or republication not permitted without written consent of the publisher
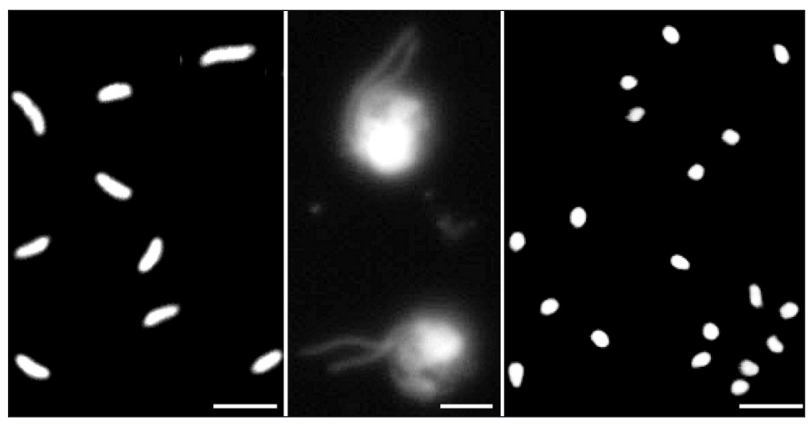

Epifluorescence microscopy photographs of the flagellate Cafeteria roenbergensis (centre) and a bacterial prey (Vibrio vulnificus) in its non-starved (left) and starved (right) physiological states. Scalebars $=2.5 \mu \mathrm{m}$

Photos: R. Anderson

\section{INTRODUCTION}

In marine pelagic environments, suspended bacteria are strongly influenced by both top-down (predation) and bottom-up (resources) controlling forces. Concentrations of organic substrates and inorganic nutrients are generally very low, requiring physiological adaptations for efficient uptake and utilization of substrates as well as for long-term survival under carbon and energy limitation. In addition, pelagic environments offer little refuge against predation by bacterivorous protists, making it necessary for bacteria to develop strategies to decrease their vulnerability. How bacterial commu- 
nities cope with these 2 selective forces has been the focus of numerous studies, revealing a wide range of mechanisms of resistance to protist grazing (Hahn \& Höfle 2001, Jürgens \& Matz 2002, Pernthaler 2005) and a well-characterized carbon-starvation response (Kjelleberg 1993, Morita 1997). However, few studies have analyzed the response to the 2 forces jointly, centring on the potential ideal for planktonic prokaryotes, an adaptive response able to cope simultaneously with both substrate limitation and grazing pressure.

To date, the physiological and molecular mechanisms of the starvation response have been studied in detail for a number of bacteria, such as Vibrio spp. (Kjelleberg 1993, McDougald et al. 2001, 2003), Enterobacteria (Jenkins et al. 1988, Galdiereo et al. 1994, Brauer et al. 2006) and others (Wrangstadh et al. 1986, Redon et al. 2005, Johnson et al. 2006). For these model organisms, the final outcome is so-called nongrowing 'ultramicrobacteria' which are highly resistant to diverse stress factors (e.g. ultraviolet light, chemical oxidants and high temperatures); they remain viable for extended periods (from weeks to months or years), and they can recover to normally growing cells given the addition of appropriate substrates. Interestingly, one of these adaptations miniaturization of the cells - is known to be a major factor leading to decreased vulnerability towards protist predation, due to a lowered grazer feeding efficiency on smaller bacterial cells (Gonzalez et al. 1990, Šimek et al. 1994, Posch et al. 1999). This could therefore constitute a mechanism - directly developed or as an indirect benefit of the starvation survival response-for carbon-starved bacteria to decrease their vulnerability towards grazers. Additionally, it becomes plausible to consider that the dominance of small or ultramicrobacterial cells among planktonic prokaryotic communities could be due partly to the combination of a high abundance of cells in the starvation survival state and a preferential elimination of bacteria of larger cell size by predators, particularly bacterivorous protists.

However, despite the potential importance of small cell size, it alone may not be sufficient for long-term survival of starvation-adapted, non-growing cells in the presence of protist predators. For most interception-feeding flagellates there is no physical limit to the uptake of small particles, as these organisms can ingest even viruses (Gonzalez \& Suttle 1993) and colloids (Sherr 1988, Tranvik et al. 1993), though not at the same rates as larger particles. Geometric models predict that the clearance rate of interception feeders decreases approximately with the square of the particle radius (Spielman 1977, Fenchel 1982a). This encounter-based size selectivity has been confirmed in feeding studies with fluorescent beads; these studies revealed that particles $<0.5 \mu \mathrm{m}$ are removed by typical bacterivorous nanoflagellates with an efficiency 4 to 6 times lower than that for particles of $1 \mu \mathrm{m}$ (Jürgens \& Matz 2002). Extrapolated to the natural environment, this would imply that-in situations where protist grazing accounts for the removal of bacterial standing stocks within 1 or a few days - small cell size would prolong survival to only 1 to 2 wk. These first-order estimates show that miniaturization of cell size alone would not enable long-term survival in the presence of bacterial grazers.

The aspects considered above, combined with the fact that the starvation survival programme confers a high, long-term resistance to abiotic stress factors, raises the question as to whether carbon-starved cells are also capable of prolonged survival in the presence of protist grazers. It has been speculated that the starvation-induced differentiation programme, which results in cross-protection against different stress factors, might also involve an increased protection against predators, e.g. by resisting the digestive enzymes inside protist food vacuoles (Jürgens \& Matz 2002). Similar effects have been observed for bacteria with certain cell wall structures, such as Gram-positive bacteria (Gonzalez et al. 1990, Iriberri et al. 1994, Tarao et al. 2009), for certain pathogens (e.g. Legionella) inside protists and macrophages (Barker \& Brown 1994), and for bacteria that secrete certain macromolecules and proteins (Greub \& Raoult 2004). Additionally, other resistance mechanisms could act at different stages of the interaction between bacteria and protists (i.e. avoiding capture or ingestion) (Matz et al. 2002, Montagnes et al. 2008).

In the present study, we aimed to take the first step of assessing whether the potential exists for carbonstarved bacteria to become less vulnerable to protist grazing, thus creating a basis for future studies on long-term survival and potential resistance mechanisms. To this end, we selected 3 model bacteria with a clearly characterized carbon-starvation respons, but which nevertheless differ in their lifestyle strategies. Vibrio vulnificus, found mostly in coastal temperate waters and often associated with plankton, shellfish and fish (Oliver 2006), and Photobacterium angustum, which was isolated from surface coastal waters, are both copiotrophic organisms with relatively large and fast growing cells; these organisms quickly react to carbon limitation by forming the aforementioned starvation survival ultramicrobacterial cells. Conversely, Sphingopyxis alaskensis is a model oligotroph that grows with a constant maximum growth rate on low concentrations of substrates and maintains a relatively small cell volume (Lauro et al. 2009). We used the simple but effective approach of comparing protist growth rates on starved vs. non-starved cells. This provides an 
integrated measure of the grazers' ability to capture, ingest and digest bacterial prey and the subsequent efficiency in transforming it into protist biomass. Therefore, this methodology, though not revealing specific processes, encompasses both the possible resistance mechanisms of these bacteria, and the potential differences in nutritional value between starved and non-starved cells.

\section{MATERIALS AND METHODS}

Bacterial strains and pre-cultures. The 3 bacterial strains used in this study, their specific starvation responses, and their subsequent increase in resistance to abiotic stress factors, have been described previously: Sphingopyxis alaskensis RB2256 (Schut et al. 1993, Schut 1994, Cavicchioli et al. 2003); Photobacterium angustum S14 (formerly Vibrio angustum) (Humphrey et al. 1983, Albertson et al. 1990, Nyström et al. 1992) and Vibrio vulnificus M06-24/O (Wright et al. 1990, Morton \& Oliver 1994). All strains were obtained from the CMB (Centre for Marine BioInnovation, UNSW, Sydney) and were maintained as glycerol stocks at $-80^{\circ} \mathrm{C}$.

Vibrio vulnificus and Photobacterium angustum were routinely grown from glycerol stocks on Luria Broth agar with $2 \% \mathrm{NaCl}$ (LB20) and MMM2000 (Marine Minimal Medium (MMM) with $2 \mathrm{~g} \mathrm{l}^{-1}$ of glucose (Östling et al. 1991); for all our solutions, $50 \mathrm{ng} \mathrm{l}^{-1}$ of vitamin $\mathrm{B}_{12}$ were added after autoclaving (Cavicchioli et al. 1999). Sphingopyxis alaskensis did not grow well on LB20, so VNSS agar (Mårdén et al. 1985) was used instead. In all cases, incubation was at $30^{\circ} \mathrm{C}$, with orbital shaking at $150 \mathrm{rpm}$ for liquid cultures.

Starved bacterial cultures were obtained as previously described (Holmquist \& Kjelleberg 1993), with some modification. Bacteria were grown in MMM2000 until an optical density corresponding to mid-exponential phase was reached $-\mathrm{OD}_{610}=0.2$ to 0.3 for Vibrio vulnificus and Photobacterium angustum, and $\mathrm{OD}_{433}=$ 0.3 for Sphingopyxis alaskensis (D. McDougald \&. L. Ting pers. comm.). Cultures were then washed with MMM, resuspended in the same medium, and allowed to starve for $72 \mathrm{~h}$ to ensure that the cells were fully adapted to long-term starvation conditions (Kjelleberg 1993).

Non-starved bacterial cultures were obtained from overnight cultures grown in MMM2000, corresponding to mid- to late-exponential growth phase. Starved and non-starved bacterial cultures to be used in a given experiment were inoculated from the same plate. With Sphingopyxis alaskensis, additional cleaning steps with MMM proved to be necessary, for both the non-starved and starved cultures, because strong bacterial growth was observed in the first grazing experiment with Cafeteria roenbergensis. This was likely due to the fact that this bacterium has broadspecificity, high-affinity uptake systems, enabling efficient substrate scavenging (Cavicchioli et al. 2003), and it can grow on low levels of nutrients (Williams et al. 2009) such as those present in the inoculum.

Cafeteria roenbergensis pre-cultures. The widespread marine bicosoecid nanoflagellate $C$. roenbergensis (Fenchel \& Patterson 1988) was selected as a model predator in tests prior to the experiments because of its ability to grow well on the selected prey and under the growth conditions used in this study (data not shown). Two different stocks of C. roenbergensis were used. For the first experiment with Photobacterium angustum and the experiment with Vibrio vulnificus, we used an axenic culture of C. roenbergensis from the CMB (described in Matz et al. 2005), while in all other experiments we used a culture from the Leibniz Institute for Baltic Sea Research (reference IOW23). Both were isolated from the Baltic Sea by A. P. Mylnikov. Cultures were routinely grown in MMM at room temperature $\left(23\right.$ to $\left.25^{\circ} \mathrm{C}\right)$ with moderate orbital shaking, using the bacterium to be tested in the experiment as food source.

To eradicate indigenous bacteria in the IOW23 cultures and obtain a protist culture with the desired bacteria as sole prey, we carried out serial dilutions in multiwell plates containing $\mathrm{MMM}$ as the medium. Protists were allowed to grow for 1 to $2 \mathrm{~d}$ at room temperature, with light orbital shaking and the desired bacteria as added food source. New multiwell plates were then inoculated from the highest dilutions at which growth of the protist was observed. This process was repeated until only the desired bacterial strain was detected (inspected by fluorescence microscopy and/or colony morphology on plates) and the final cultures were then used to inoculate the protist precultures. The efficiency of the method was tested in the second experiment with Photobacterium angustum with an immunofluorescence assay using polyclonal antibodies against $P$. angustum, as previously described (Christoffersen et al. 1997).

Growth experiments. For each experiment, batch cultures were inoculated in tissue culture flasks (Sarstedt) containing MMM as medium, using a standard protist concentration of $10^{3}$ flagellates $\mathrm{ml}^{-1}$ (obtained from the same protist pre-culture for both treatments), and 6 different initial bacterial concentrations of starved or non-starved cells, ranging from $10^{6}$ to $10^{8}$ bacteria $\mathrm{ml}^{-1}$. As controls, we prepared treatments with an intermediate bacterial concentration of $\sim 10^{7}$ cells $\mathrm{ml}^{-1}$ and no protists. Flasks were incubated at room temperature $\left(23\right.$ to $\left.25^{\circ} \mathrm{C}\right)$, with moderate orbital shaking, for 60 to $72 \mathrm{~h}$. Samples were taken every $4 \mathrm{~h}$ 
during the day and immediately fixed with $2 \%$ formaldehyde.

In total, 5 experiments were carried out: 2 with Photobacterium angustum (the first of which tested only growth on starved bacteria); 1 with Vibrio vulnificus; and 2 with Sphingopyxis alaskensis. Hereafter, these experiments are referred to, respectively, as Expts P.a.1 and P.a.2; Expt V.v; and Expts S.a.1 and S.a.2. For Expt S.a.1, due to the active bacterial growth during incubation with flagellates, only data for the growth of the flagellate on the non-starved bacterial treatment are shown, and this is referred to as flagellate growth on actively growing bacteria. Data from the starved bacterial treatment were excluded from further analysis because the fact that there was bacterial growth was an obvious indication that they were no longer in the starvation survival state.

Enumeration of organisms and biovolume measurements. For bacterial enumeration, fixed subsamples were filtered onto black polycarbonate filters (0.2 $\mathrm{mm}$ pore size; $25 \mathrm{~mm}$ diameter; Whatman) and stained with 4',6-diamidino-2-phenylindole (DAPI; $0.01 \mathrm{mg} \mathrm{ml}^{-1}$ ). For protist enumeration, the same procedure was employed using filters of pore size $0.8 \mu \mathrm{m}$ (Whatman). Samples were observed under a Zeiss Axioskop 2 mot plus microscope (Carl Zeiss), and a minimum of 200 bacterial cells (1000× magnification) and 100 flagellate cells (630× magnification) were counted per sample using filter set 02 (Carl Zeiss).

For measurements of bacterial cell size, image acquisition and analysis were performed using the CellP Image analysis software (Soft Imaging System) and an F-View camera (Soft Imaging System). Images were processed as previously described (Posch et al. 2009), with a modification of the morphological filters: Erosion, Morphological Opening and Dilatation. A total of 200 to 250 cells were analyzed (Massana et al. 1997), and cell volumes were calculated using the formula described by Bjørnsen (1986). The accuracy of the method was tested by calibration with fluorescent beads of known size.

Size distributions, based on cell volumes, were determined for each bacterial population, and the average length-to-width ratio was calculated for larger size classes as Ferret max/Ferret min (respectively, the maximum and minimum values between tangents circulating at angle $\alpha 0,10,20 \ldots 180^{\circ}$ around the particle). Size distributions were determined for control treatments without flagellates at the start of the experiment, and for treatments with protists, at intermediate to high bacterial concentrations, for later time points during the experiment. This should reveal possible changes in bacterial morphology, e.g. due to nutrient regeneration by the grazers. The time points studied were selected to cover the whole exponential phase of flagellate growth, in some cases extending beyond this time period. Statistical comparison was done by means of parametric tests when possible ( $t$-test or analysis of variance (ANOVA), see Table 1), but, on occasion, the distribution of bacterial cell sizes was not normal, requiring the use of non-parametric tests (Mann Whitney $U$-test)

Data analysis and statistics. For all experiments and treatments, flagellate and bacterial numbers were followed over time at all bacterial concentrations. Analysis was conducted with data obtained from the first 36 to $40 \mathrm{~h}$ of the experiment, and initial bacterial numbers were determined from samples taken immediately after inoculation of the experimental flasks, to avoid errors arising from the carry over of the bacterium from the flagellate inoculum. Total initial biovolumes inoculated in each experimental flask were determined by multiplying the initial concentration by multiplying the initial bacterial concentration by the mean cell volume calculated for the corresponding physiological state.

Net flagellate growth rates were obtained by linear regression of the natural logarithm of the Cafeteria roenbergensis concentration against time for each inoculated concentration of bacterial prey (starved and nonstarved) (Fenchel 1982b). Data for flagellate growth rate and initial bacterial concentration or biovolume were fitted by iteration to a hyperbolic function:

$$
\mu=x \mu_{\max } /\left(K_{\mathrm{s}}+x\right)
$$

where $\mu=$ growth rate $\left(\mathrm{d}^{-1}\right) ; \mu_{\max }=$ maximum growth rate $\left(\mathrm{d}^{-1}\right) ; \mathrm{x}=$ prey concentration or biovolume available; and $K_{\mathrm{s}}=$ half saturation constant for growth. Uncertainties in the estimates of the regression coefficients are expressed by the corresponding $95 \%$ confidence intervals and asymptotic standard errors (see Table 2).

As an indication of the minimum number of bacteria needed for flagellate growth, theoretical threshold bacterial concentrations were calculated as previously described (Eccleston-Parry \& Leadbeater 1994).

Finally, as a measure of the decrease in bacterial populations in the experimental flasks, bacterial loss rates were determined during the exponential phase of bacterial decrease (coinciding with the flagellate exponential growth phase) for each treatment and bacterial concentration as follows:

$$
\left[\left(\ln N_{\mathrm{t}}-\ln N_{0}\right) /\left(t_{t}-t_{0}\right)\right]-\left[\left(\ln C_{t}-\ln C_{0}\right) /\left(t_{t}-t_{0}\right)\right]
$$

where $N_{\mathrm{t}}$ and $N_{0}$ are, respectively, the final and initial concentrations of bacteria in the test flasks (with protists); $C_{t}$ and $C_{0}$ are, respectively, the final and initial concentrations of bacteria in the control flasks (without protists); and $t_{t}$ and $t_{0}$ are, respectively, the final and initial time points.

Statistical analyses were performed with the SPSS 15.0 (SPSS) and SigmaPlot10.0 (Systat Software) software packages. 
Fig. 1. Size distribution of the bacterial prey populations at the start of the experiments. Relative frequencies of the different size classes are shown for Photobacterium angustum S14: Expt P.a.2, non-starved $\left(A_{;} n\right)($ number of cells measured $=269)$, and starved $(B ; n=288) ; V i b$ rio vulnificus M06-24/O: Expt V.v, non-starved $\left(\mathrm{C}_{i} \mathrm{n}=250\right)$, and starved ( $\mathrm{D} ; \mathrm{n}=234)$; and Sphingopyxis alaskensis RB2256: Expt S.a.1, actively growing $\left(E_{;} n=235\right)$, Expt S.a.2, non-starved $\left(F_{;} n=211\right)$, and starved $(G ; n=204)$. Average length:width ratios for larger size classes (indicated by the dashed lines) are also plotted
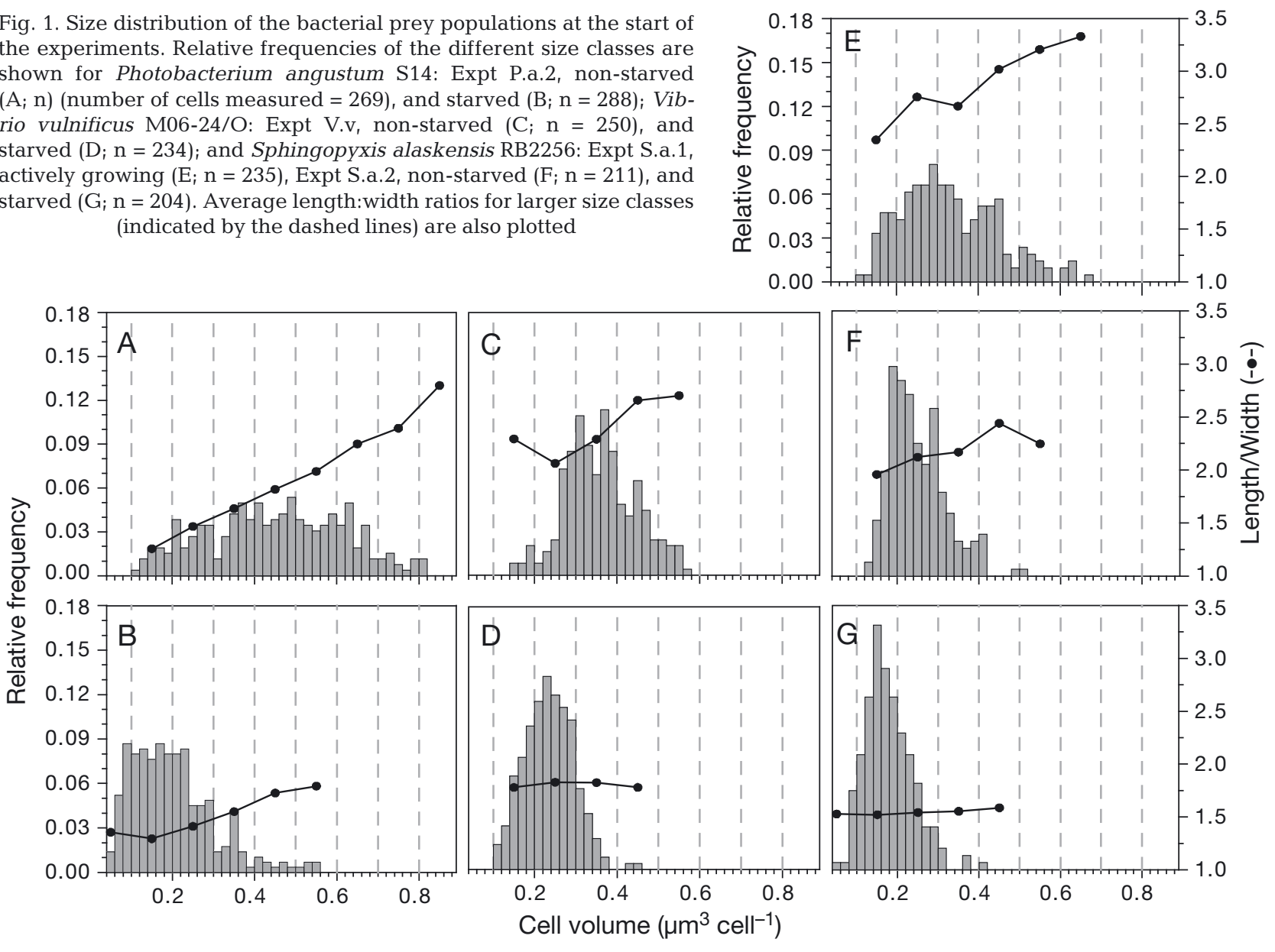

\section{RESULTS}

\section{Bacterial population characteristics}

Photobacterium angustum in its non-starved state is a rod-shaped bacterium $(0.82 \times 1.4 \mu \mathrm{m}$, median width and length respectively) with a median volume of $0.46 \mu^{3}$. Starved cells are smaller, with a median volume of $0.18 \mu^{3}$ and a more coccus-like morphology $(0.70 \times 0.89 \mu \mathrm{m})$. Observing the populations as whole, non-starved bacteria had a more heterogeneous size distribution, covering a wide range of size classes, and possessed higher and more variable length-to-width ratios (Fig. 1A,B; only data from Expt S.a.2 is shown for starved bacteria because cell size distributions were very similar in both experiments).

Vibrio vulnificus has a smaller volume (median

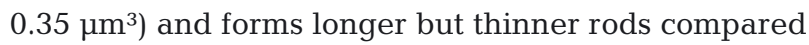
with Photobacterium angustum $(0.73 \times 1.69 \mu \mathrm{m})$. As a result of starvation conditions it forms shorter rods $(0.66 \times 1.19 \mu \mathrm{m})$, with a median volume of $0.23 \mu^{3}$. Cell size distributions of both populations tended towards a normal distribution, with a maximum in the median value (Fig. 1C,D). Length-to-width ratios were higher for the non-starved bacterial population.

Sphingopyxis alaskensis is a rod-shaped bacterium with decreasing sizes in its 3 physiological states, passing from a median cell volume of $0.32 \mu^{3}(0.65 \times$ $1.70 \mu \mathrm{m})$ when actively growing, to $0.23{\mu \mathrm{m}^{3}}^{3}(0.62 \times$ $1.27 \mu \mathrm{m}$ ) when non-starved (but not growing), and, finally, to $0.17 \mu \mathrm{m}^{3}(0.58 \times 1.02 \mu \mathrm{m})$ when starved. The reduction in length between the 3 physiological states was more marked than the reduction in width, as shown by the decreasing length-to-width ratios (Fig. 1E-G). Cell size distributions of the populations showed a clearer dominance of certain size classes for non-starved bacteria (Fig. 1F) and starved bacteria (Fig. 1G), while the actively growing population had a more widely spread heterogeneous distribution (Fig. 1E).

For all 3 bacterial strains, an overlap was observed between the initial cell size distributions in the different physiological states (Fig. 1). However, a significant difference was always maintained between the 2 populations, starved and non-starved, both at the start of the experiment and at later time points (Table 1; p < 
Table 2. Theoretical threshold values for flagellate growth, maximum growth rates $\left(\mu_{\max }\right)$ and half-saturation constants $\left(\mathrm{K}_{\mathrm{s}}\right)(\mathrm{in}$ terms of concentration and biovolume) for Cafeteria roenbergensis fed on the 3 bacterial species tested: Photobacterium angustum (Expts P.a.1 and P.a.2), Vibrio vulnificus (Expt V.v) and Sphingopyxis alaskensis (Expts S.a.1 and S.a.2). The last 2 parameters were calculated by iteration to a hyperbolic function based on the growth rate of the flagellate on the different bacterial concentrations and treatments ( $n=6$; see Fig. 2); the $\mathrm{R}^{2}, 95 \%$ confidence intervals (CI) and computed asymptotic standard errors (SE) for the estimated values are also shown

\begin{tabular}{|c|c|c|c|c|c|c|c|c|c|c|c|}
\hline \multirow{2}{*}{$\begin{array}{l}\text { Expt } \\
\text { and treatment }\end{array}$} & \multirow{2}{*}{$\begin{array}{l}\text { Threshold } \\
\left(10^{5} \text { cells }\right. \\
\left.\mathrm{ml}^{-1}\right)\end{array}$} & \multirow[b]{2}{*}{$\mathrm{h}^{-1}$} & & \multirow[b]{2}{*}{$\begin{array}{c}10^{6} \text { cells } \\
\mathrm{ml}^{-1}\end{array}$} & \multicolumn{2}{|c|}{$\mathrm{K}_{\mathrm{s}}$ (conc.) } & \multicolumn{3}{|c|}{$-\mathrm{K}_{\mathrm{s}}$ (biovolume) } & \multirow[t]{2}{*}{$\mathrm{R}^{2}$} \\
\hline & & & $\mathrm{SE}$ & $\mathrm{CI}$ & & $\mathrm{SE}$ & CI & $\begin{array}{c}10^{6}{\mu \mathrm{m}^{3}}^{3} \mathrm{ml}^{-1} \\
\text {. }\end{array}$ & SE & CI & \\
\hline \multicolumn{12}{|l|}{ Expt P.a.1 } \\
\hline Starved & 4.79 & 0.19 & 0.01 & {$[0.17 ; 0.21]$} & 6.45 & 1.07 & {$[4.35 ; 8.55]$} & 1.29 & 0.21 & {$[0.88 ; 1.7]$} & 0.99 \\
\hline \multicolumn{12}{|l|}{ Expt P.a.2 } \\
\hline Non-starved & 6.77 & 0.26 & 0.04 & {$[0.18 ; 0.34]$} & 5.85 & 2.92 & {$[0.13 ; 11.6]$} & 2.93 & 1.53 & {$[-0.1 ; 5.93]$} & 0.88 \\
\hline Starved & 3.57 & 0.25 & 0.05 & {$[0.15 ; 0.35]$} & 7.45 & 4.34 & {$[-1 ; 15.9]$} & 1.58 & 0.89 & {$[-0.2 ; 3.32]$} & 0.88 \\
\hline \multicolumn{12}{|l|}{ Expt V.v } \\
\hline Non-starved & 4.26 & 0.21 & 0.02 & {$[0.17 ; 0.25]$} & 2.72 & 1.29 & {$[0.19 ; 5.25]$} & 0.99 & 0.47 & {$[0.07 ; 1.91]$} & 0.86 \\
\hline Starved & - & - & - & - & - & - & - & - & - & - & - \\
\hline \multicolumn{12}{|l|}{ Expt S.a.1 } \\
\hline Actively growing & 0.05 & 0.3 & 0.00 & {$[0.30 ; 0.30]$} & 0.69 & 0.08 & {$[0.53 ; 0.85]$} & 0.23 & 0.03 & {$[0.17 ; 0.29]$} & 0.98 \\
\hline \multicolumn{12}{|l|}{ Expt S.a.2 } \\
\hline Non-starved & 7.54 & 0.24 & 0.02 & {$[0.20 ; 0.27]$} & 7.40 & 2.41 & {$[2.68 ; 12.1]$} & 1.86 & 0.60 & {$[0.68 ; 3.04]$} & 0.86 \\
\hline Starved & 20.7 & 0.12 & 0.02 & {$[0.08 ; 0.16]$} & 2.39 & 2.07 & {$[-1.7 ; 6.45]$} & 0.43 & 0.37 & {$[-0.3 ; 1.15]$} & 0.35 \\
\hline
\end{tabular}

was observed for almost all other concentrations tested. From the lowest to the highest initial bacterial concentration inoculated, a respective decrease in flagellate numbers of $60,70,35,84$ and $5 \%$ was observed within the first $27 \mathrm{~h}$ of incubation (data not shown).

Finally, when fed with Sphingopyxis alaskensis, clear differences were observed in the growth of the flagellates on actively growing, non-starved and starved cells (Fig. 2E,F). Calculated $\mu_{\max }$ were highest for non-starved bacteria and lowest for starved bacteria (Table 2), with standard errors and $95 \%$ confidence intervals in no case overlapping. Theoretical threshold values correspondingly showed the inverse pattern. $\mathrm{K}_{\mathrm{s}}$ values, however, were conversely higher for the nonstarved treatment than for the starved one, but data from the latter bacterial treatment should be treated with caution because the data points tended to cluster together, gave the only hyperbolic fit with low $\mathrm{R}^{2}$, and presented estimated $\mathrm{K}_{\mathrm{s}}$ values with very high standard errors (Table 2).

Overall, protist growth resulted in a corresponding decline in bacterial numbers, with bacterial loss rates increasing with protist growth rates (Fig. 3). As an exception, in the treatment with actively growing Sphingopyxis alaskensis, bacterial growth exceeded mortality, though a tendency towards lower bacterial growth with increased protist growth was still observed (Fig. 3C,F). In control treatments, with the exception of actively growing bacteria, and test treatments in which no protist growth was detected, bacterial loss rates remained around $0 \mathrm{~h}^{-1}$ (the average value for all control treatments was $0.0009 \pm 0.005 \mathrm{~h}^{-1}$, and
$0.004 \pm 0.01 \mathrm{~h}^{-1}$ for treatments where no protist growth was detected).

\section{DISCUSSION}

\section{Methodological aspects}

In the present study, we compared the growth of a bacterivorous flagellate, Cafeteria roenbergensis, on 3 model bacterial strains harvested in different physiological states: carbon-starved, non-growing and exponentially growing. To ensure that bacteria had remained in the desired physiological state throughout the duration of the experiment, analysis was restricted to the first 36 to $40 \mathrm{~h}$ sampled, and cell size was employed as an indicator of change in the physiological state during the experiment. We recognize that, by employing this measure, we potentially ignore certain effects that may occur prior to an increase in cell size (i.e. changes in cell-surface characteristics or excretion of certain substances). However, the response of carbon-starved bacteria to the appearance of a new carbon source, for example by the regeneration of nutrients through protist feeding, is very fast (Kjelleberg 1993, Morita 1997), and thus would soon be detected as shifts in the distribution of cell size in the population. This measure showed that the bacterial populations in most cases retained a constant cell volume throughout the experiments and that a significant difference was always maintained between the starved and nonstarved treatments (Table 1). 

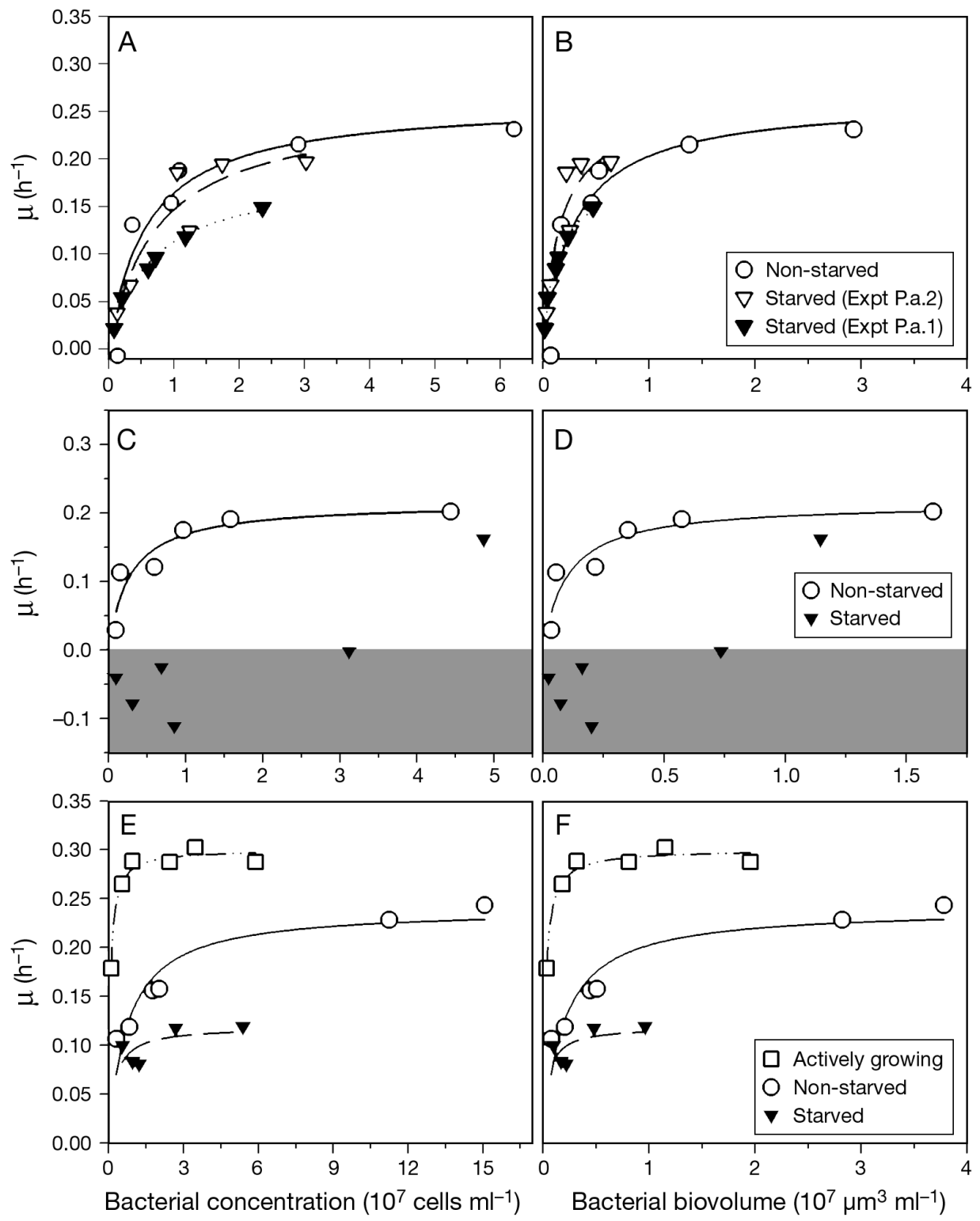

Fig. 2. Growth rate $(\mu)$ of Cafeteria roenbergensis fed on different initial bacterial concentrations, and corresponding biovolumes, of the 3 model bacteria in their different physiological states: (A,B) Photobacterium angustum S14 (Expts P.a.1 and P.a.2); (C,D) Vibrio vulnificus M06-24/O (Expt V.v); and (E,F) Sphingopyxis alaskensis RB2256 (Expts S.a.1 and S.a.2). Shaded zones indicate negative growth rates for the flagellate. Hyperbolic fits are represented by the straight and dashed lines (further information is given in Table 2)

At a bacterial strain level, the mean values of cell volume from our experiments were comparable to those reported previously, with the exception of Sphingopyxis alaskensis. This strain was shown to have a constant small size of $<0.1 \mu^{3}$ in prior studies (Schut et al. 1993, Eguchi et al. 1996), whereas we observed a change from $0.16 \mu \mathrm{m}^{3}$ in its carbon-starved state to $0.32 \mu \mathrm{m}^{3}$ when growing. Nevertheless, the identity of the strain used was positively confirmed by the 16S rRNA gene sequences $(100 \%$ similarity), and similar increases in cell size were also observed in other recent studies with this bacterium (L. Ting pers. comm.), indicating that there may be certain phenotypic changes in this strain compared to studies performed in earlier years.

In the second experiment with Photobacterium angustum S14 as the food source (Expt P.a.2), small levels of contaminant bacteria were detected at the start of the experiments. However, this contaminant remained after a final dilution of $10^{10}$ of the initial protist culture (after successive dilution steps) and the 


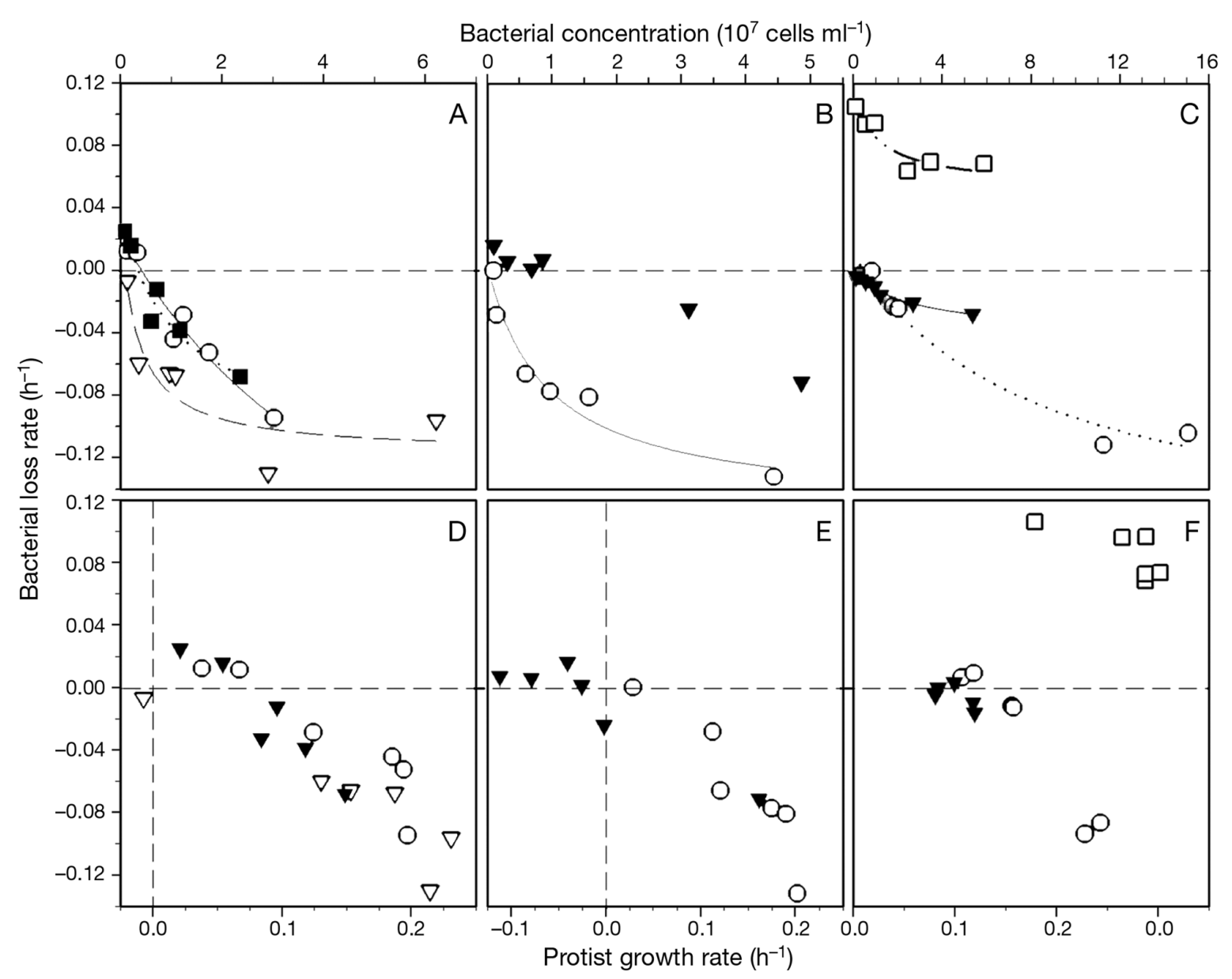

Fig. 3. Bacterial loss rates in relation to $(A-C)$ the initial bacterial concentration inoculated (hyperbolic fits are also plotted $\left(\mathrm{R}^{2}>\right.$ 0.81 in all cases)), and to (D-F) the protist growth rate. Data are shown for experiments with (A,D) Photobacterium angustum, (B,E) Vibrio vulnificus M06-24/O, and (C,F) Sphingopyxis alaskensis RB2256. O: non-starved bacteria; $\nabla$ : starved bacteria; $\square$ : actively growing bacteria. For $P$. angustum, where 2 experiments with starved bacteria were conducted: $\boldsymbol{\nabla}$, data from Expt P.a. 1 ;, data from Expt P.a.2. Dashed vertical and horizontal lines serve as reference to $0 \mathrm{~h}^{-1}$ protist growth rates or bacterial loss rates

experimental results did not differ from those obtained in Expt P.a.1, which employed an axenic culture. Therefore, we concluded that the contaminant bacteria were probably not preferentially grazed upon by Cafeteria roenbergensis, and appeared to have no effect on the experimental outcome.

\section{Protist growth on starved vs. non-starved bacteria}

The results obtained in this study indicate speciesspecific differences in the vulnerability of carbonstarved bacteria, even among the closely related strains Photobacterium angustum and Vibrio vulnificus (Ruimy et al. 1994). Cafeteria roenbergensis grew well on all 3 strains of bacteria in their nonstarved state, achieving maximal growth rates which were in the range of those previously reported for this flagellate (Gonzalez et al. 1993). In contrast, marked differences were observed when comparing protist growth on starved vs. non-starved cells of each bacterial strain.

Cafeteria roenbergensis exhibited equal growth when offered a comparable amount of starved and non-starved cells of Photobacterium angustum (Fig. 2A,B), indicating that this bacterium was an equally good food source for the flagellate in both physiological states, and that no apparent resistance mechanisms existed. Higher threshold values for starved bacteria and the tendency towards higher $\mathrm{K}_{\mathrm{s}}$ values (Table 2) could even point towards a slightly better nutritional quality in this physiological state. A higher growth efficiency of flagellates when feeding on starved bacteria was also demonstrated in a previous study (Gonzalez et al. 1993). Furthermore, the results obtained with $P$. angustum are also evidence that there is not necessarily an energy constraint for flagellates feeding on smaller prey particles. This is 
contrary to observations from an earlier study (Boenigk et al. 2006), which found lower growth rates for flagellates feeding on smaller sized bacteria. However, in their study, different bacterial strains were compared instead of different sized cells of the same strain, which makes other effects possible, such as inter-specific variations in food quality and grazing resistance. Also, differences in the behaviour of the protist species studied should be considered.

In contrast to Photobacterium angustum, starved Vibrio vulnificus did not support flagellate growth, and protist numbers declined strongly in the first $27 \mathrm{~h}$, except at the highest bacterial concentration tested. This drastic negative response at low prey concentrations is too strong to be due to a simple starvation response caused by a decrease in food quality (Fenchel 1987) and suggests the presence of bacterial resistance or repellent mechanisms. As we did not analyze the bacteria-protist interactions in detail, e.g. by live video microscopy (Boenigk \& Arndt 2000), we do not know at which stage of the feeding process $V$. vulnificus resisted grazing. Potentially, ingestion of bacteria could be avoided due to receptor-mediated repellent effects (Matz et al. 2002); there could be a post-ingestional mechanism involved, causing ingested bacteria to be egested after entering the food vacuoles (Boenigk et al. 2001) or allowing them to undergo the vacuole passage without being harmed by digestive enzymes (King \& Shotts 1988, Barker \& Brown 1994); or antiprotozoal factors could be produced at different stages of the feeding process, as has been seen for Vibrio cholerae during biofilm formation (Matz et al. 2005).

The observed exception to the overall pattern with Vibrio vulnificus as prey, namely, the positive protist growth at the highest bacterial concentration, would need further examination. The drastic negative response of the flagellates at lower bacterial concentrations does not support the explanation of a compensation of low food quality by a much higher food concentration. As a possible alternative, it remains to be examined whether high concentrations of this bacterial strain trigger regulatory shifts, e.g. by components involved in quorum sensing, known to affect both virulence and the starvation survival response in Vibrio strains (McDougald et al. 2000, 2001, 2003, Brackman et al. 2009). Nevertheless, this is, to our knowledge, the first documented case of a bacterial strain which can change from a highly edible to an unpalatable food when entering the starvation state.

Finally, Cafeteria roenbergensis also exhibited differences in growth when fed on different concentrations and biovolumes of the 3 physiological states of Sphingopyxis alaskensis. However, in contrast to the experiment with Vibrio vulnificus, no deleterious effect on the protists was observed. The observed reduction in growth probably points to a gradual decrease in food quality from actively growing to carbon-starved cells. It has been shown that both ingestion (Shannon et al. 2007) and growth rates (Grover \& Chrzanowski 2009) of bacterivorous flagellates are affected by the nutritional quality of the bacterial prey, although, in these studies, mainly a variable C:N:P stoichiometry of the offered bacterial strains was taken into account.

\section{Conclusions and outlook}

In the present study, using predator-prey model systems, we show (1) that miniaturization of cell size alone is not sufficient to lower grazing vulnerability, and (2) that some bacterial strains could possess efficient (yet to be examined) defence mechanisms that accompany the starvation survival programme and result in drastic changes in their edibility. As future work, the following points remain to be elucidated in order to determine the relevance and universality of the model systems used in this study:

- Further model systems should be tested, including different bacterial phylogenetic groups and grazers, in order to discern general patterns in the effect of bacterial carbon starvation on grazing vulnerability; - Comprehensive studies of the underlying mechanisms should be carried out in cases where decreased vulnerability of carbon-starved bacteria is observed, such as in the present study with Vibrio vulnificus as food source;

- Adequate methodologies should be developed to assess the prevalence of the carbon starvation state in natural bacterial communities and its impact on grazer vulnerability. Furthermore, the effect of a varied prey pool (different bacterial strains in different physiological states) on prey vulnerability and prey selectivity should be analyzed in detail to obtain an accurate vision of what occurs in natural environments.

Acknowledgements. This study was supported by the Leibniz Institute for Baltic Sea Research (IOW), the German Science Foundation (grant number JU 367/10-1, issued to K.J.), the Programme for the Formation of Researchers from the Department of Education, Universities and Research of the Basque Government (grant issued to R.A.) and the Australian Research Council (Discovery grant number DP0770711 to D.M. and S.K.).We thank L. Tan for providing axenic flagellate cultures, L. Ting and R. Cavicchioli for useful information and comments on Sphingopyxis alaskensis, C. Wagner for advice on the statistical analysis of the data, C. Bruckner for helpful suggestions on the manuscript, and C. Meeske for technical support confirming the identity of $S$. alaskensis RB2256. 


\section{LITERATURE CITED}

Albertson NH, Nyström T, Kjelleberg S (1990) Exoprotease activity of two marine bacteria during starvation. Appl Environ Microbiol 56:218-223

Barker J, Brown MRW (1994) Trojan Horses of the microbial world: protozoa and the survival of bacterial pathogens in the environment. Microbiology 140:1253-1259

Bjørnsen PK (1986) Automatic determination of bacterioplankton biomass by image analysis. Appl Environ Microbiol 51:1199-1204

Boenigk J, Arndt H (2000) Particle handling during interception feeding by four species of heterotrophic nanoflagellates. J Eukaryot Microbiol 47:350-358

Boenigk J, Matz C, Jürgens K, Arndt H (2001) Confusing selective feeding with differential digestion in bacterivorous nanoflagellates. J Eukaryot Microbiol 48:425-432

Boenigk J, Pfandl K, Hansen PJ (2006) Exploring strategies for nanoflagellates living in a 'wet desert'. Aquat Microb Ecol 44:71-83

Brackman G, Celen S, Baruah K, Bossier P, Van Calenbergh S, Nelis HJ, Coenye T (2009) AI-2 quorum-sensing inhibitors affect the starvation response and reduce virulence in several Vibrio species, most likely by interfering with LuxPQ. Microbiology 155:4114-4122

Brauer MJ, Yuan J, Bennett BD, Lu W, Kimball E, Botstein D, Rabinowitz JD (2006) Conservation of the metabolomic response to starvation across two divergent microbes. Proc Natl Acad Sci USA 103:19302-19307

> Cavicchioli R, Fegatella F, Ostrowski M, Eguchi M, Gottschal J (1999) Sphingomonads from marine environments. J Ind Microbiol Biotechnol 23:268-272

Cavicchioli R, Ostrowski M, Fegatella F, Goodchild A, GuixaBoixereu N (2003) Life under nutrient limitation in oligotrophic marine environments: an eco/physiological perspective of Sphingopyxis alaskensis (formerly Sphingomonas alaskensis). Microb Ecol 45:203-217

> Christoffersen K, Nybroe O, Jürgens K, Hansen M (1997) Measurement of bacterivory by heterotrophic nanoflagellates using immunofluorescence labelling of ingested cells. Aquat Microb Ecol 13:127-134

Eccleston-Parry JD, Leadbeater BSC (1994) A comparison of the growth kinetics of six marine heterotrophic nanoflagellates fed with one bacterial species. Mar Ecol Prog Ser 105:167-177

Eguchi M, Nishikawa T, MacDonald $\mathrm{K}$, Cavicchioli R, Gottschal JC, Kjelleberg S (1996) Responses to stress and nutrient availability by the marine ultramicrobacterium Sphingomonas sp. strain RB2256. Appl Environ Microbiol 62:1287-1294

Fenchel T (1982a) Ecology of heterotrophic flagellates. I. Some important forms and their functional morphology. Mar Ecol Prog Ser 8:211-223

Fenchel T (1982b) Ecology of heterotrophic microflagellates. II. Bioenergetics and growth. Mar Ecol Prog Ser 8:225-231

Fenchel T (1987) Ecology of protozoa. The biology of freeliving phagotrophic protists. In: Brock TD (ed) Brock/ Springer series in contemporary bioscience. Science Tech, Madison, WI

Fenchel T, Patterson DJ (1988) Cafeteria roenbergensis nov. gen., nov. sp., a heterotrophic microflagellate from marine plankton. Mar Microb Food Webs 3:9-19

> Galdiereo ED, Donnarumma G, DeMartino L, Marcatili A, Del'Ero GC, Merone A (1994) Effect of low-nutrient seawater on morphology, chemical composition, and virulence of Salmonella typhimurium. Arch Microbiol 162:41-47

Gonzalez JM, Suttle CA (1993) Grazing by marine nanofla- gellates on viruses and virus-sized particles: ingestion and digestion. Mar Ecol Prog Ser 94:1-10

Gonzalez JM, Sherr EB, Sherr BF (1990) Size-selective grazing on bacteria by natural assemblages of estuarine flagellates and ciliates. Appl Environ Microbiol 56:583-589

Gonzalez JM, Sherr EB, Sherr BF (1993) Differential feeding by marine flagellates on growing versus starving, and on motile versus nonmotile bacterial prey. Mar Ecol Prog Ser 102:257-267

Greub G, Raoult D (2004) Microorganisms resistant to freeliving amoebae. Clin Microbiol Rev 17:413-433

Grover JP, Chrzanowski TH (2009) Dynamics and nutritional ecology of a nanoflagellate preying upon bacteria. Environ Microbiol 58:231-243

Hahn MW, Höfle MG (2001) Grazing of protozoa and its effect on populations of aquatic bacteria. FEMS Microbiol Ecol 35:113-121

Holmquist L, Kjelleberg S (1993) Changes in viability, respiratory activity and morphology of the marine Vibrio sp strain S14 during starvation of individual nutrients and subsequent recovery. FEMS Microbiol Ecol 12:215-223

Humphrey B, Kjelleberg S, Marshall KC (1983) Responses of marine bacteria under starvation conditions at a solidwater interface. Appl Environ Microbiol 45:43-47

Iriberri J, Ayo B, Artolozaga I, Barcina I, Egea L (1994) Grazing on allochthonous vs autochthonous bacteria in river water. Lett Appl Microbiol 18:12-14

Jenkins DE, Schultz JE, Matin A (1988) Starvation-induced cross protection against heat or $\mathrm{H}_{2} \mathrm{O}_{2}$ challenge in Escherichia coli. J Bacteriol 170:3910-3914

Johnson DR, Park J, Kukor J, Abriola L (2006) Effect of carbon starvation on toluene degradation activity by toluene monooxygenase-expressing bacteria. Biodegradation 17: 437-445

Jürgens K, Matz C (2002) Predation as a shaping force for the phenotypic and genotypic composition of planktonic bacteria. Ant Leeuwenhoek 81:413-434

King C, Shotts EB Jr (1988) Enhancement of Edwardsiella tarda and Aeromonas salmonicida through ingestion by the ciliated protozoan Tetrahymena pyriformis. FEMS Microbiol Lett 51:95-100

Kjelleberg S (1993) Starvation in bacteria. Plenum Press, New York, NY

Lauro FM, McDougald D, Thomas T, Williams TJ and others (2009) The genomic basis of trophic strategy in marine bacteria. Proc Natl Acad Sci USA 106:15527-15533

Mårdén P, Tunlid A, Malmcrona-Friberg K, Odham G, Kjelleberg $S$ (1985) Physiological and morphological changes during short-term starvation of marine bacterial isolates. Arch Microbiol 142:326-332

Massana R, Gasol JM, Bjørnsen PK, Blackburn N and others (1997) Measurement of bacterial size via image analysis of epifluorescence preparations: description of an inexpensive system and solutions to some of the most common problems. Sci Mar 61:397-407

Matz C, Boenigk J, Arndt H, Jürgens K (2002) Role of bacterial phenotypic traits in selective feeding of the heterotrophic nanoflagellate Spumella sp. Aquat Microb Ecol 27: $137-148$

Matz C, McDougald D, Moreno AM, Yung PY, Yildiz FH, Kjelleberg $S$ (2005) Biofilm formation and phenotypic variation enhance predation-driven persistence of Vibrio cholerae. Proc Natl Acad Sci USA 102:16819-16824

> McDougald D, Rice SA, Kjelleberg S (2000) The marine pathogen Vibrio vulnificus encodes a putative homologue of the Vibrio harveyi regulatory gene, luxR: a genetic and phylogenetic comparison. Gene 248:213-221 
McDougald D, Rice SA, Kjelleberg S (2001) SmcR-dependent regulation of adaptive phenotypes in Vibrio vulnificus. J Bacteriol 183:758-762

McDougald D, Srinivasan S, Rice SA, Kjelleberg S (2003) Signal-mediated cross-talk regulates stress adaptation in Vibrio species. Microbiology 149:1923-1933

Montagnes DJS, Barbosa AB, Boenigk J, Davidson K and others (2008) Selective feeding behaviour of key free-living protists: avenues for continued study. Aquat Microb Ecol 53:83-98

Morita RY (1997) Bacteria in oligotrophic environment: starvation-survival lifestyle. In: Reddy CA, Chakrabarty AM, Demain AL, Tiedje JM (eds) Chapman \& Hall Microbiology Series. Chapman \& Hall, New York, NY

Morton DS, Oliver JD (1994) Induction of carbon starvationinduced proteins in Vibrio vulnificus. Appl Environ Microbiol 60:3653-3659

Nyström T, Olsson RM, Kjelleberg S (1992) Survival, stress resistance, and alterations in protein expression in the marine Vibrio sp. strain S14 during starvation for different individual nutrients. Appl Environ Microbiol 58:55-65

Oliver JD (2006) Vibrio vulnificus. In: Thompson FL, Austin B, Swings J (eds) The biology of vibrios. American Society for Microbiology, Washington, DC, p 349-367

Östling J, Goodman A, Kjelleberg S (1991) Behaviour of IncP1 plasmids and a miniMu transposon in a marine Vibrio sp.: isolation of a starvation inducible lac operon fusion. FEMS Microbiol Ecol 86:83-94

Pernthaler J (2005) Predation on prokaryotes in the water column and its ecological implications. Nat Rev Microbiol 3:537-546

Posch T, Šimek K, Vrba J, Pernthaler J and others (1999) Predator-induced changes of bacterial size-structure and productivity studied on an experimental microbial community. Aquat Microb Ecol 18:235-246

Posch T, Franzoi J, Prader M, Salcher MM (2009) New image analysis tool to study biomass and morphotypes of three major bacterioplankton groups in an alpine lake. Aquat Microb Ecol 54:113-126

Redon E, Loubiere P, Cocaign-Bousquet M (2005) Transcriptome analysis of the progressive adaptation of Lactococcus lactis to carbon starvation. J Bacteriol 187:3589-3592

Ruimy R, Breittmayer V, Elbaze P, Lafay B, Boussemart O, Gauthiery M, Christen R (1994) Phylogenetic analysis and assessment of the genera Vibrio, Photobacterium, Aeromonas and Plesiomonas deduced from small-subunit rRNA sequences. Int J Syst Bacteriol 44:416-426

Schut F (1994) Ecophysiology of a marine ultramicrobacterium. PhD thesis, University of Groningen, Groningen

Schut F, de Vries EJ, Gottschal JC, Robertson BR, Harder W, Prins RA, Button DK (1993) Isolation of typical marine bacteria by dilution culture: growth, maintenance, and characteristics of isolates under laboratory conditions. Appl Environ Microbiol 59:2150-2160

> Shannon SP, Chrzanowski TH, Grover JP (2007) Prey food quality affects flagellate ingestion rates. Microb Ecol 53:$66-73$

Sherr EB (1988) Direct use of high-molecular-weight polysaccharide by heterotrophic flagellates. Nature 335:348-351

Šimek K, Vrba J, Hartman P (1994) Size-selective feeding by Cyclidium sp. on bacterioplankton and various sizes of cultured bacteria. FEMS Microbiol Ecol 14:157-167

Spielman LA (1977) Particle capture from low-speed laminar flows. Annu Rev Fluid Mech 9:297-319

Tarao M, Jezbera J, Hahn MW (2009) Involvement of cell surface structures in size-independent grazing resistance of freshwater Actinobacteria. Appl Environ Microbiol 75: 4720-4726

Tranvik LJ, Sherr EB, Sherr BF (1993) Uptake and utilization of colloidal DOM by heterotrophic flagellates in seawater. Mar Ecol Prog Ser 92:301-309

Williams TJ, Ertan H, Ting L, Cavicchioli R (2009) Carbon and nitrogen substrate utilization in the marine bacterium Sphingopyxis alaskensis strain RB2256. ISME J 3: 1036-1052

Wrangstadh M, Conway PL, Kjelleberg S (1986) The production and release of an extracellular polysaccharide during starvation of a marine Pseudomonas sp. and the effect thereof on adhesion. Arch Microbiol 145:220-227

> Wright AC, Simpson LM, Oliver JD, Morris JG Jr (1990) Phenotypic evaluation of acapsular transposon mutants of Vibrio vulnificus. Infect Immun 58:1769-1773

Submitted: September 27, 2010; Accepted: May 12, 2011 Proofs received from author(s): July 2, 2011
Editorial responsibility: Karel Šimek,

České Budějovice, Czech Republic 